\title{
Effects of Country Variables on Brand Strength: Moderating by Brand Life Cycle and Cultural Identification
}

\author{
Hsiu-Li Chen
}

\begin{abstract}
The purpose of this study is to empirically examine the country variables on brand strength via brand attitude. Moreover, the moderating roles of brand life cycle and cultural identification are examined. $A 2 \times 2 \times 4$ research design ((Taiwan/China) $\times$ (high-involvement products and low-involvement products) $\times$ (Taiwan, China, Japan, and USA)) and LISREL technique are employed to examine the effects of country variables on brand strength. The results of the study find that country of origin has significantly positive effects on brand attitude and brand strength for both Taiwan and China sample. In addition, brand life cycle and cultural identification play moderating role between country of original and brand attitude.
\end{abstract}

Index Terms-Country variables, brand attitude, brand strength, brand life cycle

\section{INTRODUCTION}

According to the American Marketing Association, a brand is a "name, term, sign, symbol, or design, or a combination of them, intended to identify the goods and services of one seller or group of sellers and to differentiate them from those of competition". Management attention to brand as an intangible asset has certainly increased substantially since the 1990s. The brand is a special intangible that in many businesses is the most important asset [1]. "If this business were split up, I would give you the land and bricks and mortar, and I would take the brands and trade marks, and I would fare better than you." quoted by John Stuart, former chairman of Quaker oats. This is a very nice quote that illustrates the values of brands and trademarks. Needless to say, companies that manage a successful brand can enjoy higher sales, repeat purchases, and help meet consumer expectations [2][3].

There are many factors that may affect consumers' brand choice decision. Evidence has built up over several decades that country variables (such as country-of-origin (COO), country image, or country stereotype) may have substantial effects on consumers' brand choice and purchase decisions [4]-[7]. Martin and Eroglu (1993) define COO as the total of all descriptive, inferential and informational beliefs one has about a particular country. Researchers have studied the $\mathrm{COO}$ effect in many different nations and have incorporated political, economic, technological and social factors to measure country image [8][9]. COO may have effects on consumers' attitude toward a country's product or a brand. Therefore, the first objective of this paper is to investigate the effect of $\mathrm{COO}$ on consumers' attitudes toward the brand and the mediating role of brand attitude.
The concept of brand architecture has been developed since the 1990s by brand positioning specialist but lack of much attention. As suggested by Goodyear (1996), the evolution of brand differs in different economies in each country and the economic cycle of a country is a proxy to the evolution of the brand [10]. The Goodyear model also suggests that an observation of income levels in a country serve as a signal on how different branding strategies can be adopted. In global marketing context, it needs to understand how consumer see the role of a brand and then link this with brand attitude. Therefore, the second objective of the paper is to test if the COO has stronger effect on brand attitude when the brand is in his higher life cycle then when the brand is not.

Next, cultural differences may be the primary obstacle to developing internationally accepted brands and communicating with global consumers, especially those who live in developing countries withmore traditional societies [11]. Literature has documented cultural differences have effects in consumer purchase behavior [12][13]. Some studies have found that consumers tend to more easily adopt products that come from source countries perceived to have a similar political climate or a similar belief system of their country [14]-[16]. Therefore, the third objective of this study is to test if there are differences of COO, brand attitude and brand strength between two countries that have difference cultures identification with the brand origin country.

\section{BACK GROUND LITERATURE AND RESEARCH HYPOTHESES}

This study employs country variables and consumer value as antecedent variables, attitude toward a brand product as a mediator, and brand strength as the outcome. Also, Taiwan and China are set as two consuming countries. An overview of the conceptual framework is displayed in Figure 1.

\section{A. COO, Consumer Patriotism, and Values on Brand Attitude}

Bilkey and Nes (1982) describe the country of origin product cue as a product's sourcing country and state that it was usually communicated by the phrase, "Made in (name of country)." Han $(1988,1990)$ indicates that the rational or cognitive factor of $\mathrm{COO}$ is the perceived quality of foreign product which tends to be evaluated according to technical, advancement, prestige, workmanship, economy, and service [17]. 


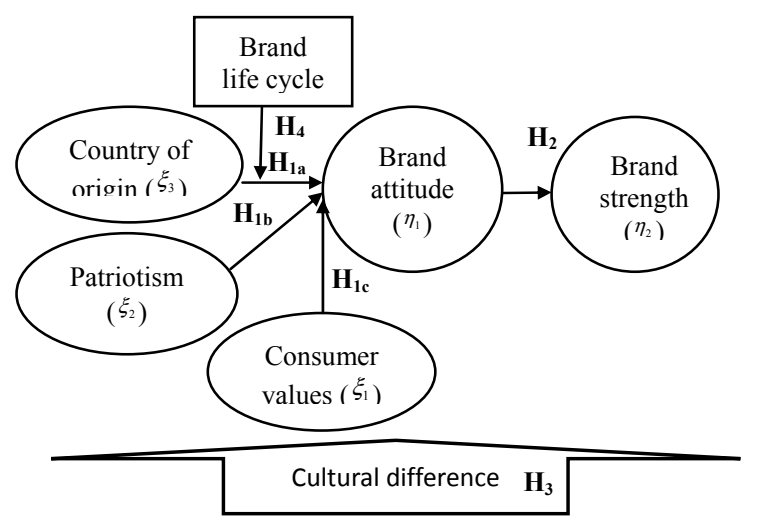

Fig 1 The conceptual framework of this study

The alternative argues that consumer's choices are also influenced by affective factors (i.e. consumer patriotism) [18]-[20]. Zajonc (1980) cites a number of references to support his contentions that affective reactions are primary, basic, inescapable, irrevocable, and difficult to verbalize that can become separated from content, and need not involve cognition [21].

Anderson and Cunningham (1972) argue that consumer's dogmatism, conservatism, and status concern have a negative impact on a consumer's attitude toward a foreign product. Zajonc and Markus (1982) propose that patriotic responses toward domestic products or against foreign products may lead to behavioral responses. Factors such as ethnocentrism, feelings of national pride, and personal experience of the global vision may also influence attitude toward a foreign product. Past studies also indicate that primarily due to consumers' patriotism, there is a tendency for consumers to more favorably evaluate their own country's products than foreign consumers do [5][8]. Therefore, higher consumer patriotism results in a negative attitude toward a foreign product.

Robbins (1993) regards that value is an ideology, attitude, belief, and thinking which will lead to the ultimate outcome. Like attitudes, values represent consumer beliefs about life and acceptable behavior [22][23]. However, values, unlike attitudes, transcend situations or events and are more enduring. Values are important in the need recognition stage of consumer decision marking process. Personal values help explain how we answer "Is this brand for me?"[24]. Rose (1994) further indicates values could influence consumers in buying fashion products. Early research concerning values is influenced most by Rokeach Value Scale (RVS).

According to Blackwell Miniard, and Engel (2006), attitudes are global or overall evaluative judgments. Mitchell \& Olson (1981) argue that consumer attitude is an internal evaluation toward a product or brand. In general, when a consumer has higher perceived quality of a foreign product, he will form a more positive attitude toward that product.

Accordingly, the following hypotheses are proposed:

$\mathrm{H}_{1}$ : Country-of-origin has a positive effect on consumers' attitudes toward foreign brand.

$\mathrm{H}_{1 \mathrm{~b}}$ : Consumers' patriotism has a negative effect on consumers' attitudes toward foreign products.

$\mathrm{H}_{1 \mathrm{c}}$ : Consumers' values have positive effects on brand attitude, where 'competence values and 'personal value' have larger effects on brand attitude than 'moral values' and 'social values'.

\section{B. Brand Attitude toward Brand Strength}

The concept of brand strength is derived from brand value which is acuminated by consumers' brand preference. Stronger brand strength could reduce consumers' risk perceptions of the brand extension [25][26]. Feldwick (1996) indicates that brand strength is a part of brand equity which is measured by the degree of contact between the customer and the brand. Previous studies show that brands with stronger brand strength could induce larger leverage effect than those of brands with weaker brand strengths. In order to examine brand strength on consumers' attitudes toward foreign products, the following hypothesis is proposed:

$\mathrm{H}_{2}$ : Consumers brand attitudes have significantly positive effects on brand strength.

\section{Consuming Country-specific Effect}

Han (1990) also suggests that stronger COO effects exist for products from a country with a dissimilar value system and socio/cultural climate than for products from a similar country. In addition, $\mathrm{COO}$ effects seem to be particularly strong in developing countries, particularly toward products from more highly-developed countries [17][7]. Other studies in the past have hypothesized that $\mathrm{COO}$ effects may differ across countries, depending on consumer's perceived similarities with the source country's value system. Klein, Ettenson, and Morris (1998) establish an animosity model related to foreign product purchases, and they argue that culture-specific factors influence the weight given to the country-of-origin in product evaluations. Consequently, they argue that consumers' attitudes toward foreign products may be governed by culture-specific factors other than product quality [27]. Thus, the following hypotheses are proposed:

$\mathrm{H}_{3}$ : Consumer may form more positive attitude toward foreign product when there is higher cultural identification between sourcing country and consuming country than when there is not.

\section{Brand Life Cycle Effect on COO and Brand Attitude}

The so-called brand life cycle management is to determine the stage of the brand in order to meet consumers' needs. According to Goodyear (1996), the roles of brand (brand life cycle) have six stages: unbranded, brand as reference, brand as personality, brand as icon, brand as company and brand as policy. Consumers' brand attitudes may be different in different brand life cycle. It is possible to conclude that different economic stages of various Asian countries in different economic development signify the differences in how brands are evolved [28][29]. Thus, the following hypotheses are proposed:

$\mathrm{H}_{4}$ : COO may have stronger effect on brand attitude when the brand is in higher stages then when it is in lower stage.

\section{RESEARCH DESIGN}

\section{A. Countries under study and Product Modes}

As mentioned earlier, this study utilizes a design of 
multi-attributes setting, i.e., two-culture respondents and two product-categories mode and four foreign product countries $(2 \times 2 \times 4)$ is examined. First, Taiwan and China are under review and set as the consuming countries.

\section{B. Sampling}

The data was collected from January 2010 to March 2010. Out of a total sample of 430, 298 questionnaires were returned for Taiwan's sampling, a response rate of $69.3 \%$; and 91 were returned for China sampling, a response rate of $46.8 \%$. With regard to the sample size, Tanaka (1987) suggests that sample sizes of 100 are strong lower bounds when considering maximum likelihood estimates of structural equation models [20].

\section{Questionnaire and Measures}

The questionnaire was organized into six sections. In the first section, country-of-origin (country image) effects are assessed. As suggested by Han (1990), the COO items are measured on five items at the level of specific product categories: technical advancement, prestige value, workmanship, economy, and serviceability. The five measurements are measured on seven point semantic differential scales.

In the second section, a consumer's attitude toward foreign products is measured. In accordance with $\mathrm{ABC}$ model of attitudes that an attitude has three components: affects, behavior, and cognition [30][31]. Therefore, the attitude toward foreign products is evaluated on a seven-point semantic scale with cognition and affective items: the consumer's rating of a specific foreign product's 'overall quality' and the consumer's affective rating of the product [17]. Next, consumers' intentions to buy foreign products are measured on five-point scales ranging from "would definitely intend to buy" to "would definitely intend not to buy" [21][17].

In the third section, respondents are asked about their familiarity with the selected products and their identification with foreign culture (i.e., Japanese culture, American culture, Taiwanese culture and Chinese culture); these two items are measured on seven-point semantic scales.

In the fourth section, the consumer's patriotism is evaluated. Consumer patriotism is measured by assessing the subject's emotional intensity toward the following statements: (1) I should buy Taiwan's/China products because I am a Taiwanese/Chinese; (2) Foreign imports are and will be hurting Taiwan's/Chinese industry. (3) Foreign imports are and will be replacing domestic jobs (4) I feel guilty if I choose to buy foreign products instead of Taiwan's/Chinese products [32]. The items are measured on seven-point scales ranging from "strongly agree" to "strongly disagree". Next, the RVS included a set of instrumental values, or actions need to take to achieve these terminal values [33] is adopted as the measurement of personal value. The questionnaire concludes by asking for consumers' basic data.

\section{Reliability and Validity}

All the measures indicate an acceptable level of reliability (Cronbach's $\alpha$ ) that range from 0.78 to 0.96 . The content validity is based on the literature review and expert opinion, the content validity for the survey instrument is established. Moreover, KMO value larger than 0.68, indicates a well content validity.

\section{ANALYSIS AND RESULTS}

\section{A. Hypotheses test}

Figure 1 and Table 1 show a structural equation model and the definitions of latent/observed endogenous/exogenous variables for the hypotheses testing. Three country variables and personal value are set to be latent exogenous variables: value ( $\left.\xi_{1}\right)$, 'consumer patriotism' $\left(\xi_{2}\right)$ and 'COO' $\left(\xi_{3}\right)$. Consumers' attitudes toward foreign products $\left(\eta_{1}\right)$ and brand strength $\left(\eta_{2}\right)$ are set up to be latent endogenous variables. The measurement model will be estimated by the LISREL technique [34].

The parameter estimates for measurements of observed exogenous variables, parameter estimates for causal model, and goodness of fit measures for the whole model are exhibited in Table 1. Before discussing the hypothesized relationship, assessments about the overall fit of the model to the data are made. The goodness-of-fit measures of the whole model are judged by means of GFI, AGFI, RMRSE [34]. Table1 shows that across four foreign products and two consuming countries, the fit for all cases is reasonably good where GFIs and around 0.90 in Taiwan' case and 0.80 in China's case and RMSEA values are in acceptable level [35]. In addition, all factor loadings are statistically significant, which indicates the effectiveness of the measurements employed in the study. Each individual relationship is discussed as follows.

\section{B. Hypothesis 1, 2 and 4}

According to hypothesis 1a, $\mathrm{COO}$ has significant influence on consumers' attitudes toward foreign products. Table 1 shows that the $\gamma_{13}$ estimates are positive and are significant in all the cases (both beer and personal computer). The positive sign of $\gamma_{13}$ indicates that the higher the COO image an individual has formed, the more positive attitude toward a foreign product he has. Therefore, hypothesis 1 may be not rejected.

Hypothesis $1 \mathrm{~b}$ indicates that consumer patriotism has a negative impact on consumer attitude towards a foreign product. As can be seen in Table 1 that effect of consumer patriotism on brand attitude toward foreign product $\left(\gamma_{12}\right)$ is mixed. First, for beer, both Taiwanese and Chinese samples show that $\gamma_{12}$ is not significant across four countries of origin. Moreover, some of the $\gamma_{12}$ coefficients are positive. It indicates that consumer patriotism have no significant effects on brand attitude.

TABLE 1 PARAMETER ESTIMATES, GFI MEASURES AND TOTAL EFFECTS: PERSONAL COMPUTER VS. BEER

\begin{tabular}{r|c|c|c|c}
\hline Product & \multicolumn{4}{|c}{ Personal Computer comes from } \\
\hline $\begin{array}{c}\text { Consuming } \\
\text { country: Taiwan }\end{array}$ & USA & Japan & China & Taiwan \\
\hline $\begin{array}{c}\text { Value } \rightarrow \text { Brand } \\
\text { attitude } \gamma_{11}\end{array}$ & $0.1426^{*}$ & $0.1447^{* *}$ & 0.0963 & -0.414 \\
\hline $\begin{array}{c}\text { Patriotism } \rightarrow \text { Brand } \\
\text { attitude } \gamma_{12}\end{array}$ & -0.0543 & $0.1522^{* *}$ & $0.1996^{* *}$ & -0.0800 \\
\hline
\end{tabular}




\begin{tabular}{|c|c|c|c|c|}
\hline $\begin{array}{l}\mathrm{COO} \rightarrow \mathrm{Brand} \\
\text { attitude } \gamma_{13}\end{array}$ & $0.2379 * * *$ & $0.4040 * * *$ & $0.4412 * * *$ & $0.2831 * * *$ \\
\hline $\begin{array}{c}\text { Brand } \\
\text { attitude } \rightarrow \text { Brand } \\
\text { strength } \beta_{21}\end{array}$ & $0.9055 * * *$ & $0.8390 * * *$ & $0.8889 * * *$ & $0.7500 * * *$ \\
\hline$\chi^{2} / \mathrm{df}$ & 1.8757 & 1.8243 & 1.9490 & 2.1710 \\
\hline GFI & 0.9046 & 0.9076 & 0.9021 & 0.8959 \\
\hline RMS & 0.0557 & 0.0533 & 0.0554 & 0.0617 \\
\hline $\begin{array}{c}\text { Consuming } \\
\text { country: China }\end{array}$ & USA & Japan & China & Taiwan \\
\hline $\begin{array}{l}\text { Value } \rightarrow \text { Brand } \\
\text { attitude } \gamma_{11}\end{array}$ & $0.2388 * *$ & $0.2234 * *$ & -0.1701 & 0.1842 \\
\hline $\begin{array}{c}\text { Patriotism } \rightarrow \text { Brand } \\
\text { attitude } \gamma_{12}\end{array}$ & 0.0468 & 0.0466 & 0.0949 & $-0.2335^{* *}$ \\
\hline $\begin{array}{c}\mathrm{COO} \rightarrow \text { Brand } \\
\text { attitude }_{\gamma_{13}}\end{array}$ & $0.3003 * *$ & $0.6109 * * *$ & $0.4341 * * *$ & $0.2500 * *$ \\
\hline $\begin{array}{c}\text { Brand } \\
\text { attitude } \rightarrow \text { Brand } \\
\text { strength } \\
\beta_{21}\end{array}$ & $0.9692 * * *$ & $0.8894 * * *$ & $0.9341 * * *$ & $0.9113 * * *$ \\
\hline$\chi^{2} / \mathrm{df}$ & 3.0029 & 2.1605 & 2.3624 & 2.0976 \\
\hline GFI & 0.7428 & 0.7516 & 0.7258 & 0.7401 \\
\hline RMS & 0.1332 & 0.0984 & 0.1087 & 0.1010 \\
\hline Product & \multicolumn{4}{|c|}{ Beer comes from } \\
\hline $\begin{array}{c}\text { Consuming } \\
\text { country: Taiwan }\end{array}$ & $U S A$ & Japan & China & Taiwan \\
\hline $\begin{array}{l}\text { Value } \rightarrow \text { Brand } \\
\text { attitude } \gamma_{11}\end{array}$ & -0.0393 & 0.0681 & 0.0441 & $0.1337 * *$ \\
\hline $\begin{array}{c}\text { Patriotism } \rightarrow \text { Brand } \\
\text { attitude } \gamma_{12}\end{array}$ & 0.0131 & -0.0728 & 0.0946 & 0.0495 \\
\hline $\begin{array}{l}\mathrm{COO} \rightarrow \text { Brand } \\
\text { attitude } \gamma_{13}\end{array}$ & $0.4976^{* * *}$ & $0.4047 * * *$ & $0.1838 * *$ & $0.5751 * * *$ \\
\hline $\begin{array}{c}\text { Brand } \\
\text { attitude } \rightarrow \text { Brand } \\
\text { strength } \beta_{21}\end{array}$ & $0.8736^{* * *}$ & $0.8735^{* * *}$ & $0.9422 * * *$ & $0.7799 * * *$ \\
\hline$\chi^{2} / \mathrm{df}$ & 2.0713 & 1.8876 & 2.2281 & 2.0987 \\
\hline GFI & 0.8996 & 0.9028 & 0.8888 & 0.8979 \\
\hline RMS & 0.0587 & 0.0549 & 0.0637 & 0.0581 \\
\hline $\begin{array}{c}\text { Consuming } \\
\text { country: China } \\
\end{array}$ & USA & Japan & China & Taiwan \\
\hline $\begin{array}{l}\text { Value } \rightarrow \text { Brand } \\
\text { attitude } \gamma_{11}\end{array}$ & 0.0054 & -0.2190 & $-0.3724 * *$ & -0.1027 \\
\hline $\begin{array}{c}\text { Patriotism } \rightarrow \text { Brand } \\
\text { attitude } \gamma_{12}\end{array}$ & -0.1997 & -0.0598 & -0.0282 & 0.1795 \\
\hline $\begin{array}{c}\mathrm{COO} \rightarrow \text { Brand } \\
\text { attitude } \gamma_{13}\end{array}$ & $0.4751 * * *$ & $0.4490 * * *$ & $0.5904 * * *$ & $0.5719 * * *$ \\
\hline $\begin{array}{c}\text { Brand } \\
\text { attitude } \rightarrow \text { Brand } \\
\text { strength } \beta_{21}\end{array}$ & $0.8620 * * *$ & $0.9670 * * *$ & $0.8943 * * *$ & $0.9511 * * *$ \\
\hline$\chi^{2} / \mathrm{df}$ & 2.0957 & 2.1779 & 2.2034 & 2.6934 \\
\hline GFI & 0.7391 & 0.7453 & 0.7298 & 0.7023 \\
\hline RMS & 0.1015 & 0.0981 & 0.1066 & 0.1209 \\
\hline
\end{tabular}

Note: $* * *$ represents a significant at $5 \%$ level.

Second, for PC, Taiwanese samples show significantly positive attitude toward Japan and China PC brands and negative attitude toward USA and Taiwan's PC. On the other hand, China samples show positive (but not significant) attitude toward USA, Japan, and China PC brands but have significantly negative attitude toward Taiwan's PC. Overall, consumer patriotism does not have expected significantly effect on brand attitude toward a brand. Therefore, hypothesis $1 b$ is not supported.

By the same token, $\gamma_{11}$ indicates consumer's personal value on brand attitude. As can be seen from Table 1 that most of the coefficients are positive for four countries-of-origin and consuming countries. However, the sign of $\gamma_{11}$ are not significant. Therefore, hypothesis $1 \mathrm{c}$ is partially supported.

\section{Hypothesis 2}

Hypothesis 2 tests the effect of brand attitude toward brand strength. Table 1 shows the coefficients of $\beta_{21}$ are significantly positive across four sourcing countries, two products and two consuming countries. It implies that consumers who have higher brand attitudes are tend to agree with higher brand strength of the brands. Accordingly, hypothesis 2 is accepted.

\section{Hypothesis 3}

As mention earlier, consumers' attitudes toward foreign products may differ by cultural identification other than product quality. A pre-test has shown that Taiwan's consumers have higher cultural identification on Japan than China's consumers. A mean structure model is conducted to compare the differences in $\mathrm{COO}$, consumer patriotism, and attitudes toward products. 'Factor mean' could be used to identify the factor difference between the two groups (i.e., Taiwan vs. China). As can be seen in Table 2 that Taiwan's samples show higher $\mathrm{COO}$, brand attitude and brand strength than China samples (as factor mean is significantly positive). Accordingly, hypothesis 3 may not be rejected.

TABLE 2 FACTOR MEAN FOR JAPANESE BRAND CAUSAL PATH: TAIWAN VS. CHINA CONSUMERS

(Common Metric Completely Standardized Solution)

\begin{tabular}{|c|c|c|c|c|c|}
\hline \multirow{3}{*}{ 导 } & \multirow{3}{*}{ Items } & \multicolumn{4}{|c|}{ Taiwan vs. Japanese } \\
\hline & & \multicolumn{2}{|c|}{ Japanese Beer } & \multicolumn{2}{|c|}{ Japanese PC } \\
\hline & & $\begin{array}{l}\text { Factor } \\
\text { loading }\end{array}$ & $\begin{array}{c}\text { Factor } \\
\text { mean }\end{array}$ & $\begin{array}{l}\text { Factor } \\
\text { loading }\end{array}$ & $\begin{array}{c}\text { Factor } \\
\text { mean }\end{array}$ \\
\hline \multirow{4}{*}{ 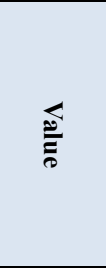 } & unbranded & $0.7972^{* * *}$ & \multirow{4}{*}{$\begin{array}{c}0.0796 \\
(1.2580)\end{array}$} & 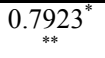 & \multirow{4}{*}{$\begin{array}{c}0.0789 \\
(1.2536)\end{array}$} \\
\hline & $\begin{array}{l}\text { Brand as } \\
\text { reference }\end{array}$ & $0.7185^{* * *}$ & & $0.7201^{*}$ & \\
\hline & $\begin{array}{c}\text { Brand as } \\
\text { personality }\end{array}$ & $0.7810^{* * *}$ & & $0.7816^{*}$ & \\
\hline & $\begin{array}{c}\text { Brand as } \\
\text { icon }\end{array}$ & $0.7379^{* * *}$ & & $\underset{* *}{0.7401^{*}}$ & \\
\hline \multirow{4}{*}{ 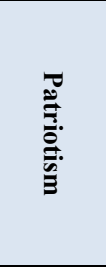 } & $\begin{array}{l}\text { Brand as } \\
\text { company }\end{array}$ & $0.4957^{* * *}$ & \multirow{4}{*}{$\begin{array}{l}-0.1834^{* *} \\
(-1.8671)\end{array}$} & $0.4954^{*}$ & \multirow{4}{*}{$\begin{array}{l}-0.1831^{* *} \\
(-1.8701)\end{array}$} \\
\hline & $\begin{array}{l}\text { Brand as } \\
\text { policy }\end{array}$ & $0.8692^{* * *}$ & & $\begin{array}{c}0.8698^{*} \\
\end{array}$ & \\
\hline & $\begin{array}{c}\text { Personal } \\
\text { value }\left(\mathrm{X}_{1}\right)\end{array}$ & $0.8730^{* * *}$ & & $0.8742^{*}$ & \\
\hline & $\begin{array}{c}\text { Social } \\
\text { value }\left(\mathrm{X}_{2}\right)\end{array}$ & $0.5945^{* * *}$ & & $\underset{* *}{0.5940^{*}}$ & \\
\hline \multirow{5}{*}{8} & $\begin{array}{l}\text { Competenc } \\
\text { e value }\left(\mathrm{X}_{3}\right)\end{array}$ & $0.8357^{* * *}$ & \multirow{5}{*}{$\begin{array}{l}1.5137^{* * *} \\
(11.1113)\end{array}$} & $0.8345^{*}$ & \multirow{5}{*}{$\begin{array}{l}0.5408^{* * *} \\
(4.4155)\end{array}$} \\
\hline & $\begin{array}{c}\text { Moral } \\
\text { value }\left(\mathrm{X}_{4}\right) \\
\end{array}$ & $0.8759^{* * *}$ & & $\underset{* *}{0.8907^{*}}$ & \\
\hline & $\begin{array}{c}\text { Tech } \\
\text { advanceme } \\
\text { nt } \\
\end{array}$ & $0.8353^{* * *}$ & & $0.8264^{*}$ & \\
\hline & Prestige & $0.7686^{* * *}$ & & $0.6672^{*}$ & \\
\hline & $\begin{array}{c}\text { Workmansh } \\
\text { ip } \\
\end{array}$ & $0.5931^{* * *}$ & & $0.6581^{*}$ & \\
\hline \multirow{3}{*}{ 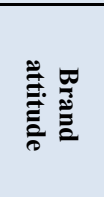 } & $\begin{array}{c}\text { Good value } \\
\text { for price } \\
\end{array}$ & $0.8491^{* * *}$ & \multirow{3}{*}{$\begin{array}{l}0.4403^{* * *} \\
(2.8145)\end{array}$} & $0.7878^{*}$ & \multirow{3}{*}{$\begin{array}{l}0.4740^{* * *} \\
(4.6346)\end{array}$} \\
\hline & Service & $0.8617^{* * *}$ & & $0.8654^{*}$ & \\
\hline & Obligation & $0.7524^{* * *}$ & & $0.7537^{*}$ & \\
\hline \multirow{2}{*}{ 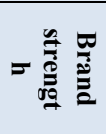 } & $\begin{array}{c}\text { Brand trend } \\
\left(\mathrm{Y}_{4}\right)\end{array}$ & $0.7667^{* * *}$ & \multirow{2}{*}{$\begin{array}{l}0.6427^{* * *} \\
(3.9292)\end{array}$} & $\begin{array}{c}0.7941^{*} \\
\end{array}$ & \multirow{2}{*}{$\begin{array}{l}0.4550^{* * *} \\
(2.8343)\end{array}$} \\
\hline & $\begin{array}{c}\text { Geographic } \\
\text { spread }\end{array}$ & $0.8246^{* * *}$ & & $0.8073^{*}$ & \\
\hline
\end{tabular}




\begin{tabular}{|c|c|c|c|c|}
\hline & $\begin{array}{c}\text { Leadership } \\
\left(\mathrm{Y}_{6}\right)\end{array}$ & $0.8941^{* * *}$ & $0.7774^{*}$ & \\
\hline & $\operatorname{Market}\left(\mathrm{Y}_{7}\right)$ & $0.9259^{* * *}$ & $0.8924^{*}$ & \\
\hline & $\begin{array}{c}\text { Stability } \\
\left(\mathrm{Y}_{8}\right)\end{array}$ & $0.9050^{* * *}$ & $0.8766^{*}$ & \\
\hline \multirow{4}{*}{ 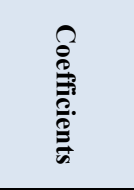 } & $\gamma_{11}$ & 0.0058 & \multicolumn{2}{|c|}{$0.1421 * *$} \\
\hline & $\gamma_{12}$ & -0.0260 & \multicolumn{2}{|c|}{$0.1380 * *$} \\
\hline & $\gamma_{13}$ & $0.3643^{* * *}$ & \multicolumn{2}{|c|}{$0.4167 * * *$} \\
\hline & $\beta_{21}$ & $0.8100^{* * *}$ & \multicolumn{2}{|c|}{$0.7596^{* * *}$} \\
\hline \multirow{2}{*}{$\begin{array}{c}\text { Goodness } \\
\text { of fit }\end{array}$} & GFI & \multirow{2}{*}{$\begin{array}{l}0.8518 \\
0.0603 \\
\end{array}$} & \multirow{2}{*}{\multicolumn{2}{|c|}{$\begin{array}{l}0.8370 \\
0.0751\end{array}$}} \\
\hline & RMR & & & \\
\hline
\end{tabular}

Note: *** represents a significant at $5 \%$ level; ** represents a significant at $10 \%$ level.

\section{E. Hypotheses 4}

In order to test the moderating effect of brand life cycle, this study combines the data of four countries. As can be seen in Table 3, for Taiwan's samples, $\gamma_{13}$ is larger in higher brand life cycle stage in beer. For China sample, $\gamma_{13}$ is larger in higher BLC stage both in beer and in PC. It implies that $\mathrm{COO}$ have higher effect on brand attitude when the brand is at his higher BLC stage then when the brand is not. Accordingly, hypothesis 4 is partially accepted.

TABLE 3 PARAMETER ESTIMATES, GFI MEASURES AND TOTAL EFFECTS: BRAND LIFE CYCLE

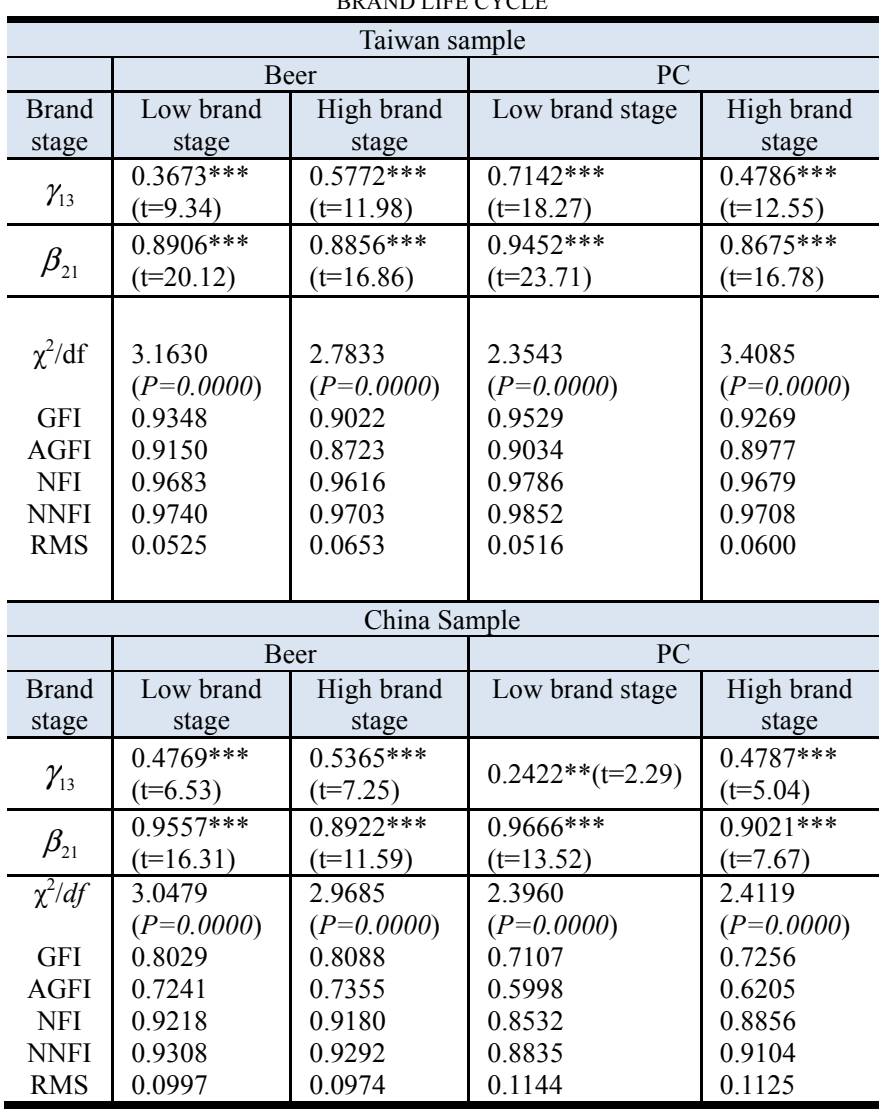

Note: $* * *$ represents a significant at $5 \%$ level.

\section{DISCUSSION AND CONCLUSIONS}

For the past decade, increasing interest in the concept of country variables and their impact on brand attitude and brand value/strength has emerged among both the academic and practitioners communities. Four specific hypotheses have been developed and tested. The results suggest that: (1) country variables may have some effects on consumer attitude toward foreign brand. Whilst, COO has a significantly positive impact on consumer attitude toward foreign products; while consumer patriotism, personal value have not a significantly effect on consumer attitude toward foreign products. As tested both in high involvement product (PC) and low involvement product (beer) we conclude that consumer patriotism seems has slight effect on consumer brand choice nowadays; (2) the hypothesis that positive product attitude exits when there is a high cultural identification between sourcing country and consuming country may not be rejected; (3) the hypothesis that $\mathrm{COO}$ has higher impact on consumers' brand attitude at higher BLC stage, than at lower BLC stage (i.e., beer may be partially supported.

\section{REFERENCES}

[1] Interbrand. (2004). Brand Valuation. 130 Fifth Avenue, New York, NY10011.

[2] Keller, K. L. (1993). Conceptualizing, measuring, and managing consumer-based brand equity, Journal of marketing, 57(1), 1-22.

[3] Keller, K. L. (2003). Strategic brand management: Building measuring and managing brand equity. Englewood Cliffs, NJ: Prentice-Hall.

[4] Schooler, R. D. (1965). Product bias in the Central American common market. Journal of Marketing Research, 2(4), 394-397.

[5] Nagashima, A. (1970). A comparison of Japanese and U.S. attitudes toward foreign products. Journal of Marketing, 34(1), 68-74.

[6] Gaedeke, R. (1973). Consumer attitudes towards products 'Made in' developing countries. Journal of Retiling, 49(2), 14-24.

[7] Bilkey, W. J., \& Nes, E., (1982). Country of origin effects in product evaluations. Journal of International Business Studies, 13(1), 89-99.

[8] Han, C. M. \& Terpstra, V. (1988). Country-of-origin effects for uni-national and bi-national products. Journal of International Business Studies, 19(2), 235-255.

[9] Johansson, J. K., Douglas, S. P. \& Nonaka, I. (1985). Assessing the impact of country of origin on product evaluation: a new methodological perspective. Journal of Marketing Research, 22(4), 388-396.

[10] Erdem, T., Swait, J., \& Valenzuela, A. (2006). Brands as Signals: A Cross-Country Validation Study. Journal of Marketing, 70(1), 34-49.

[11] Jun, J. W. \& Lee, H. S. (2007). Cultural differences in brand designs and tagline appeals. International Marketing Review, 24(4), 474-491.

[12] Aaker, J. L. \& Williams, P. (1998). "Empathy versus pride: the influence of emotional appeals arrows cultures. Journal of consumer Research, 25 (3), 241-261.

[13] Klein, J. G., R. Ettenson and M. D. Morris (1998), "The Animosity Model of Foreign Product Purchase: An Empirical Test in the People's Republic of China." Journal of Marketing, 62 (1), 89-101.

[14] Krishnakumar, P. (1974). An exploratory study of the influence of country of origin on the product images of persons from selected countries. Ph.D. dissertation, The University of Florida.

[15] Wang, C. k. \& Lamb, C. W. (1983). The impact of selected environmental forces upon consumer's willingness to buy foreign products. Journal of the Academy of Marketing Science, 11(1/2), 71-84.

[16] Gürhan-Canli, Z. \& Maheswaran, D. (2000). Cultural variations in country of origin effects. Journal of Marketing Research, 37(3), 309-317.

[17] Han, C. M. (1990). Testing the role of country image in consumer choice behavior. European Journal of Marketing, 24(6), 24-40.

[18] Zajonc, R. B. (1980). Feeling and thinking: preferences need no inferences. American Psychologists, 35(2), 151-175.

[19] Zajonc, R. B., \& Markus, H. (1982). Affective and cognitive factors in preferences. Journal of consumer research, 9(2), 123-131.

[20] Moon, B. J., \& Jain, S. C. (2002). Consumer processing of foreign advertisements: roles of country-of-origin perceptions, consumer ethnocentrism, and country attitude. International Business Review, 11(2), 117-138.

[21] Erickson, J., Chao, P. \& Johansson, J. K. (1984). Image variables in multi-attribute product evaluation: country of origin effect. Journal of Consumer Research, 11(2), 694-699.

[22] England, G. W. \& Lee, R. (1974). The relationship between managerial values and managerial success in the United States, Japan, India, and Australia. Journal of Applied Psychology. 59 (4), 411-419. 
[23] Blackwell, R. D., Miniard, P. W. \& Engel, J. F. (2006). Consumer behavior, $10^{\text {th }}$ ed. OH: Thomson South-Western.

[24] Engel, J. F., Blackwell, R. D., \& Miniard, P. W. (1990). Consumer behavior, Orlando: The Dryden Press.

[25] Kesler, L. (1987). Extensions leave brand in new area. Advertising Age, June/1: S1.

[26] Aaker, D. A., \& Keller, K. L. (1990). Consumer evaluations of brand extensions. Journal of Marketing, 54(1), 27-41.

[27] Usunier, J. C., Kocher, B., \& Czellar, S. (2006). The effect of perceived brand name--logo coherence on brand attitudes. Advances in Consumer Research, 33(1), 274-276.

[28] Goodyear, M. (1996). Divided by a common language: diversity and deception in the world of global marketing. Journal of the Market Research Society, 38 (2), 105-122.

[29] McEnally, M. R. \& de Chernatonym L. (1999). The evolving nature of branding: consumer and managerial considerations. Academy of Marketing Science Review, 99(2), 1-38.

[30] Sheth, J. N., Mittal, M., \& Newman, B. I. (1999). Customer behavior: consumer behavior and beyond. TX: Dryden Press

[31] Solomon, M. R. (2007). Consumer behavior- buying, having, and being. 7/e. Prentice Hall International, Inc.

[32] Han, C. M. (1988). The role of consumer patriotism in the choice of domestic versus foreign production. Journal of Marketing Research, 28(3), 25-32.

[33] Rokeach, M. J. \& Ball-Rokeach, A. J. (1989). Stability and change in American value priorities, 1968-1981, American Psychologist, 44(5), 547-549.

[34] Jöreskog, K. G.., \& Sörbom, D. (2003). LISREL 8: User's Reference Guide. Chicago: Scientific Software International.

[35] McDonald, R. P. \& Ho, M. R. (2002). Principles and practice in reporting structural equation analysis. Psychological Methods, 7(1), $64-82$.

Hsiu-Li Chen is professor at Dept. of International Business, Ming Chuan University, Taipei, Taiwan. Her Research interest and publications are in the areas of marketing (gray marketing and brand management) and consumer behavior. She can be contacted at: hlchen@mail.mcu.edu.tw. 